\section{Does ranitidine provide protection against acid gastroesophageal reflux?}

\author{
Daisy Verbessem MD, Frederic Camu MD, \\ Anne Van de Velde MD
}

Continuous gastroesophageal $\mathrm{pH}$ monitoring was used to evaluate the effect of ranitidine on gastroesophageal reflux (GOR) in 60 patients scheduled for elective non-gastrointestinal abdominal or gynaecological surgery. The patients were randomly assigned to receive a single dose of ranitidine $50 \mathrm{mg}$ either iv (RANIV group) or im (RANIM group) or a placebo iv (PLAC group) 90 min before surgery. The $p H$ was measured continuously for six hours in the lower oesophagus using a flexible calibrated glass electrode. $A \mathrm{pH}<4.0$ was chosen as the boundary for defining occurrence of acid GOR. Both ranitidine treatments reduced the total number of acid reflux episodes and the global reflux index $(P<0.05)$. The duration of the acid reflux episodes (sum of refluxes) and the number of acid reflux episodes longer than five minutes were markedly decreased by ranitidine but the mean duration of the reflux episodes was unaffected. The $\mathrm{pH}$ values at induction, intubation, surgical incision and extubation were similar in the PLAC and RANIV groups but more acid than in the RANIM group. The mean $p H$ of reflux episodes was less acid in both ranitidine groups than in the PLAC group $(P<0.05)$. Also the number of very acid refluxes $(p H<2.5)$ decreased with ranitidine $(P$ $<0.05$ ). Intramuscular and intravenous administration of ranitidine provide protection against gastroesophageal reflux, with shorter duration of reflux episodes occurring in the intramuscular group. Regardless of the administration of ranitidine, protection against gastroesophageal reflux is incomplete; the frequency of reflux episodes is reduced but not eliminated.

\section{Key words}

COMPLICATIONS: acid gastroesophageal reflux; GASTROINTESTINAL TRACT: antacids, oesophagus, reflux; HISTAMINE: ranitidine.

From the Department of Anaesthesiology, Flemish Free University of Brussels Medical Center, Laarbeeklaan 101, B-1090 Brussels, Belgium

Address correspondence to: Dr. F. Camu, Professor of Anaesthesiology, Department of Anaesthesiology, Flemish Free University of Brussels Medical Center, Laarbeeklaan 101, B-1090 Brussels, Belgium.

Accepted for publication 4th September, 1992.
Dans le but dëvaluer les effets de la ranitidine sur le reflux gastro-oesophagien (GOR), on utilise un monitorage continu du pH chez 60 patients programmés pour chirurgie gynécologique et non digestive. Les patients sont assignés au hasard à recevoir une seule dose de ranitidine $50 \mathrm{mg}$ soit intraveineuse (groupe RANIV) soit intramusculaire (groupe RANIM) ou un placebo intraveineux (groupe PLAC) 90 min avant la chirurgie. Le pH est mesuré de façon continue pendant six heures dans l'oesophage inférieur à l'aide d'une électrode flexible de verre calibrée. Un $\mathrm{pH}<4,0$ est choisi comme la limite d'apparition d'un GOR acide. Les deux traitements à la ranitidine diminuent le nombre total d'épisodes de reflux acide et l'index de reflux global $(P<0,05)$. La durée des épisodes de reflux acide (somme des réflexes) et le nombre des épisodes de reflux acide de plus de cinq minutes sont considérablement diminués par la ranitidine mais la durée moyenne des épisodes n'est pas modifée. Les valeurs du $\mathrm{pH}$ à linduction, lintubation, lincision et l'extubation sont identiques dans le groupe PLAC et RANIV mais plus acides que dans le groupe RANIM. Le pH mojen des épisodes de reflux est moins acide dans les groupes ranitidine que dans le groupe PLAC $(P<0,05)$. De plus, le nombre des reflux très acides $(p H<2,5)$ diminue avec la ranitidine $(P<0,05)$. L'administration intramusculaire ou intraveineuse de ranitidine protège contre le reflux gastrooesophagien et la durée des épisodes de reflux dans le groupe intramusculaire est moindre. Même après l'administration de ranitidine, la protection est incomplète; la présence des épisodes de reflux est réduite mais non éliminée.

Pulmonary aspiration of gastric contents remains a major risk of perioperative morbidity and mortality in anaesthesia. ${ }^{1-3}$ The major aetiological factors in the development of aspiration pneumonitis involve acidity of the aspirate $(\mathrm{pH}<2.5)$ combined with a regurgitation volume greater than $25 \mathrm{ml} .^{4}$ These factors have been extrapolated from animal experiments and their validity for humans has been disputed. 5,6 Silent gastro-pharyngeal regurgitation has been reported to occur in $5 \%$ of patients admitted for elective surgery. This incidence increased to $20 \%$ in patients admitted for emergency laparoscopy.? Gastroesophageal sphincter competence prevents all oc- 
currences of gastroesophageal acid reflux (GOR) from progressing to regurgitation. Indeed, the oesophagus can retain large volumes of fluid in the presence of an incompetent cardiac sphincter. ${ }^{8}$ The prevalence of troublesome GOR in adults is 5-8\%. ${ }^{9,10}$ Vomiting occurs only rarely considering the incidence of GOR although 7 to $36 \%$ of the adult population have, at least occasionally, symptoms that can be related to GOR."

Ranitidine inhibits basal and nocturnal gastric acid secretion. It is four to nine times more potent than cimetidine with a longer duration of action and fewer side effects. ${ }^{12-16}$ These $\mathbf{H}_{2}$-receptor antagonists are reported to increase gastric $\mathrm{pH}$ above 2.5 and decrease the volume of gastric aspirate. ${ }^{17-21}$ Whether they modify the incidence and characteristics of GOR has, surprisingly, not been studied in detail. This study aimed to assess the effects of a single dose of ranitidine, given preoperatively by either the iv or im route, on GOR compared with placebo, using oesophageal $\mathrm{pH}$ monitoring to quantitate the efficacy of treatment with this $\mathrm{H}_{2}$-receptor blocker, in patients without clinical history of GOR.

\section{Methods}

The protocol was approved by the Committee of Medical Ethics of the University and oral informed consent was obtained from all patients on the evening before surgery. Sixty healthy patients aged 21 to $65 \mathrm{yr}$, ASA physical status I or II, were admitted to the study. All patients required general anaesthesia with tracheal intubation for elective non gastro-intestinal abdominal or gynaecological procedures. Excluded from the trial were patients weighing $<50 \mathrm{~kg}$ or $>90 \mathrm{~kg}$, patients with a history of hiatus hernia, dyspepsia, peptic ulcer or gastro-intestinal diseases.

The patients were fasted for at least eight hours before starting the study and were brought unpremedicated to a waiting area next to the surgical theatre. Under $i v$ sedation with lorazepam, $3 \mathrm{mg}$, or midazolam, $7.5 \mathrm{mg}$, and after local anaesthesia of the nose, a $\mathrm{pH}$ electrode was introduced via the nose into the stomach. Gastric $\mathrm{pH}$ was measured and then the electrode was gently withdrawn to the gastroesophageal junction identified by a rapid $\mathrm{pH}$ change. The electrode was further withdrawn $3 \mathrm{~cm}$ and taped to the skin. The patients were randomly allocated to each treatment according to a table of random numbers. Twenty patients each received $50 \mathrm{mg}$ ranitidine either i $($ RANIV) or im (RANIM), or a similar volume of saline iv (placebo group, PLAC). Vital signs and side effects were noted every $15 \mathrm{~min}$ for $90 \mathrm{~min}$ at which time the patients were transferred to the operating room.

Anaesthesia was induced with fentanyl 50-100 $\mu \mathrm{g}$ and thiopentone $4-6 \mathrm{mg} \cdot \mathrm{kg}^{-1} i v$. Tracheal intubation was per-
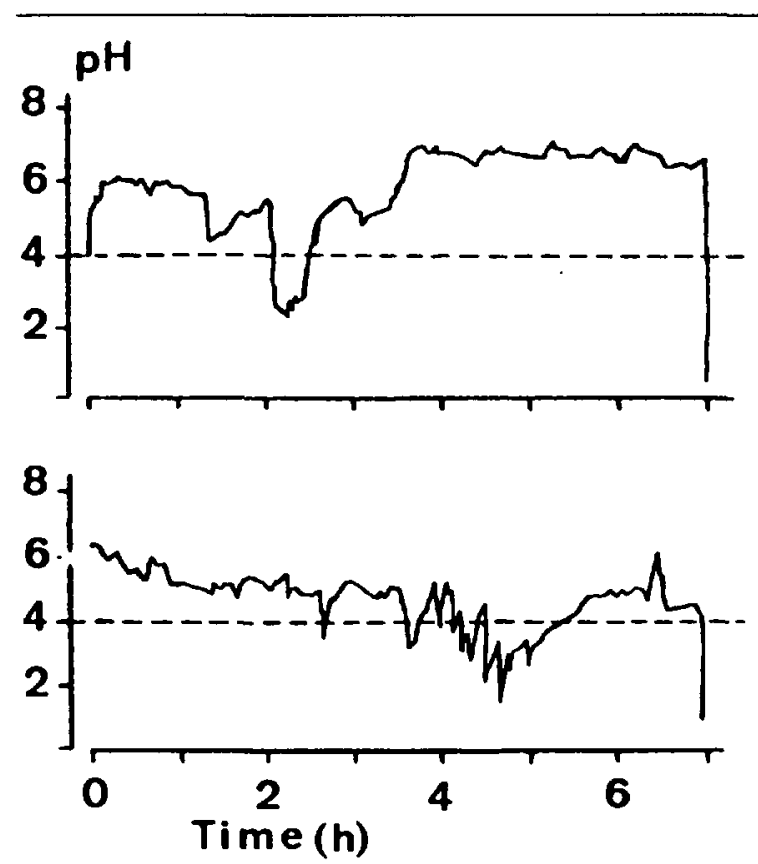

FIGURE Examples of GOR using continuous lower oesophageal pH monitoring. The broken line $(\mathrm{pH}=4)$ represents the boundary level for quantification of GOR. pH units as ordinate, time as abscissa.

formed after a bolus of succinylcholine $1 \mathrm{mg} \cdot \mathrm{kg}^{-1}$. For maintenance of anaesthesia enflurane was administered in a mixture of nitrous oxide and oxygen (70:30) with incremental doses of fentanyl and pancuronium bromide as required by surgical needs. At the end of surgery, the patients were allowed to regain spontaneous breathing, reflexes and consciousness, and following extubation of the trachea were transferred to the postanaesthesia care unit where they remained in semi-recumbent position for six hours after the ranitidine or placebo administration.

For $\mathrm{pH}$ measurements we used a GK $2801 \mathrm{C}$ flexible glass electrode (Radiometer, Copenhagen) with a maximum outer body diameter of $4.5 \mathrm{~mm}$, a pH range between 0 to 12 and a temperature range between 0 and $60^{\circ} \mathrm{C}$. Its response time $(98 \%)$ varied from 5 to $15 \mathrm{sec}$ at $37^{\circ} \mathrm{C}$. The noise level was $0.03 \mathrm{pH}$ units. Calibration of the electrode using two buffer solutions $(\mathrm{pH}=1.0$ and $\mathrm{pH}=7.0$ ) was performed before and after each study. A Memolog 600 system collected the registered $\mathrm{pH}$ values measured every $7.5 \mathrm{sec}$ into memory. At the end of the test, the data were read by computer with graphical representation of the $\mathrm{pH}$ curve obtained (Figure). $\mathrm{A} \mathrm{pH}$ of 4.0 was chosen as the boundary level because it is unequivocally different from the usual oesophageal $\mathrm{pH}$ which is close to 7 . A pH $<4$ for $30 \mathrm{sec}$ was assumed to indicate GOR. The variables calculated included the mean ambiant $\mathrm{pH}$ in the lower oesophagus, the percentage of investigation time with $\mathrm{pH}<4$ (reflux index), 
TABLE I Demographic and surgical data

\begin{tabular}{llll}
\hline & $P L A C$ & $R A N I M$ & $R A N I V$ \\
\hline$n$ & 18 & 20 & 20 \\
Sex M/F & $2 / 16$ & $2 / 18$ & $2 / 18$ \\
Age (yr) & $34.6 \pm 1.3$ & $33.8 \pm 1.7$ & $36.8 \pm 2.1$ \\
Weight (kg) & $62.8 \pm 2.0$ & $63.8 \pm 2.5$ & $65.0 \pm 2.2$ \\
Height (cm) & $165 \pm 2$ & $162 \pm 2$ & $164 \pm 1$ \\
Asa I & 16 & 18 & 18 \\
$\quad$ II & 2 & 2 & 2 \\
Duration of surgery (min) & $55 \pm 4$ & $86 \pm 10^{*}$ & $77 \pm 9^{*}$ \\
Anaesthetic agents (vol \%) & $0.82 \pm 0.04$ & $0.89 \pm 0.03$ & $0.80 \pm 0.03$ \\
Fentanyl amount ( $\mu g$ ) & $167 \pm 11$ & $213 \pm 27$ & $185 \pm 14$ \\
& & & \\
Type of surgery & & & 14 \\
Laparoscopic salpingolysis & 15 & 14 & 2 \\
Inguinal hernia & 2 & 2 & - \\
Retroperitoneal abcess & 1 & - & 3 \\
Abdominal hysterectomy & - & 4 & 1 \\
Cholecystectomy & - & - & \\
\hline
\end{tabular}

(mean data $\pm \mathrm{SEM} ;{ }^{*} P<0.05$ vs placebo).

the total duration of episodes with $\mathrm{pH}<4$ (sum of refluxes, min), the average oesophageal acid clearing time (duration of reflux episodes, $\mathrm{min}$ ), the number of episodes with $\mathrm{pH}<4$, the number of episodes of more than five minutes with $\mathrm{pH}<4$ and the incidence of very acid GOR with $\mathrm{pH}<2.5$.

Statistical evaluation included Kruskal-Wallis analysis of variance for comparison of data. Differences among treatment groups with respect to drug efficacy were analyzed by Mann-Whitney's U test. Tables of frequencies classified according to two factors were analyzed using chi-square statistic or the $G$ test to assess the hypothesis of independency between factors. $P<0.05$ was accepted as the limit of significance for rejection of the null hypothesis.

\section{Results}

Two patients from the placebo group were excluded from the analysis of data because of pregnancy. The three groups of patients were similar with respect to distribution of age, weight, height and sex ratio (Table I). Also no differences were found among groups in the type of surgery, nor in the amounts of anaesthetic agents or opiates administered. The duration of surgery was longer in both ranitidine groups than with placebo. Starting from similar initial $\mathrm{pH}$ values before drug administration, the $\mathrm{pH}$ values at selected anaesthetic events (induction, intubation, incision) were not different in the PLAC and RANIV groups but were higher in the RANIM group (Table II). Both ranitidine treatments reduced the number of total acid reflux episodes and the reflux index (Table III) but there were no important differences among
TABLE II Lower oesophageal $\mathrm{pH}$ values at selected anaesthetic events

\begin{tabular}{lccc}
\hline Group & PLAC & RANIM & RANIV \\
\hline Baseline & $6.28 \pm 0.13$ & $6.37 \pm 0.13$ & $6.24 \pm 0.10$ \\
& $(5.20-7.37)$ & $(5.31-7.48)$ & $(5.12-6.90)$ \\
Induction & $5.73 \pm 0.26$ & $6.35 \pm 0.10^{*}$ & $6.10 \pm 0.27$ \\
& $(2.96-7.25)$ & $(5.50-7.29)$ & $(1.42-7.38)$ \\
Intubation & $5.56 \pm 0.32$ & $6.26 \pm 0.11^{*}$ & $5.98 \pm 0.29$ \\
& $(1.05-6.82)$ & $(5.44-7.07)$ & $(1.33-7.36)$ \\
Incision & $5.88 \pm 0.19$ & $6.25 \pm 0.15^{*}$ & $5.86 \pm 0.29$ \\
& $(4.30-7.25)$ & $(5.47-7.58)$ & $(1.49-7.51)$ \\
Extubation & $4.29 \pm 0.46$ & $6.62 \pm 0.15^{*}$ & $5.93 \pm 0.34^{*}$ \\
& $(1.06-7.23)$ & $(5.00-7.75)$ & $(1.82-7.51)$ \\
\hline
\end{tabular}

The mean values represent the average of a single $\mathrm{pH}$ measure made at the specific event in each individual for each group. Mean values \pm SEM with range in parenthesis. ${ }^{*} P<0.05$ vs placebo)

groups for the first $90 \mathrm{~min}$ of the investigation (i.e., the time between drug administration and anaesthesia induction). The total duration of the reflux episodes with $\mathrm{pH}$ $<4$ (sum of refluxes) was shorter in both ranitidine than in the placebo treatment groups $(P<0.05)$ although the mean duration of these reflux episodes was similar in all groups. The number of patients with acid reflux episodes longer than five minutes was reduced by ranitidine $(P<0.05)$. During reflux episodes the mean $\mathrm{pH}$ value remained higher in both ranitidine groups $(P<$ 0.05 ). The mean values for the ambient $\mathrm{pH}$ in the lower oesophagus during the six hours observation period were higher in both ranitidine groups than in placebo.

Also the number of very acid refluxes $(\mathrm{pH}<2.5)$ was reduced by ranitidine $(P<0.05)$ as shown in Table IV. Fewer patients showed episodes of very acid GOR before and during anaesthesia in each ranitidine treatment group in comparison with placebo, but the incidence of such episodes in all these patients was similar. Pairwise comparisons between treatment groups revealed no differences between the effects of the im and $i v$ administration of ranitidine.

\section{Discussion}

In the present study, the placebo patients showed a high incidence of acid GOR, 58\% of these had a pH $<2.5$ and $37 \%$ lasted longer than five minutes. The considerable reduction of these very acid refluxes during the $90 \mathrm{~min}$ preceding anaesthesia in the ranitidine treated patients suggests a rapid onset of effect of ranitidine on gastric $\mathrm{pH}$. Ranitidine seemed more potent following the im route as the differences in effect with regard to the placebo group were more pronounced than in the $i v$ group. However, the total number of acid reflux episodes during the six hour investigation was similar in 
TABLE III Gastroesophageal reflux data

\begin{tabular}{|c|c|c|c|}
\hline Group & $P L A C$ & RANIM & $R A N I V$ \\
\hline \multicolumn{4}{|c|}{ Number of reflux episodes $(\mathrm{pH}<4)$} \\
\hline - Before anaesthesia & 25 & 9 & 6 \\
\hline - During anaesthesia & 28 & 4 & 5 \\
\hline - After anaesthesia & $\underline{23}$ & $\underline{2}$ & 7 \\
\hline - Total & $\overline{76}$ & $\overline{15 *}$ & $\overline{18 *}$ \\
\hline \multicolumn{4}{|l|}{ Reflux index (\%) } \\
\hline$-0-90 \mathrm{~min}$ & $8.0 \pm 3.4$ & $3.1 \pm 1.5$ & $2.2 \pm 1.3$ \\
\hline$-90 \mathrm{~min}-6 \mathrm{~h}$ & $9.9 \pm 4.2$ & $0.8 \pm 0.5 \S$ & $4.3 \pm 2.1$ \\
\hline Sum of refluxes (min) & $36.1 \pm 14.0$ & $5.3 \pm 2.6 \S$ & $13.8 \pm 6.5^{*}$ \\
\hline Duration of episodes (min) & $\begin{array}{l}8.7 \pm 1.7 \\
(0.5-74)\end{array}$ & $\begin{array}{l}4.8 \pm 1.1 \\
(0.5-15)\end{array}$ & $\begin{array}{c}8.9 \pm 3.5 \\
(0.5-59)\end{array}$ \\
\hline Refluxes episodes $\geq 5 \min (n)$ & 28 & $7^{*}$ & $7^{*}$ \\
\hline Mean $\mathrm{pH}$ of reflux episodes & $\begin{array}{c}1.69 \pm 0.12 \\
(0.50-3.94)\end{array}$ & $\begin{array}{l}2.41 \pm 0.20 \S \\
(1.49-3.91)\end{array}$ & $\begin{array}{l}2.18 \pm 0.21^{*} \\
(1.13-3.93)\end{array}$ \\
\hline Mean ambiant $\mathrm{pH}$ over $6 \mathrm{~h}$ & $\begin{array}{l}5.68 \pm 0.23 \\
(2.82-7.53)\end{array}$ & $\begin{array}{l}6.31 \pm 0.12^{*} \\
(5.45-7.52)\end{array}$ & $\begin{array}{l}6.10 \pm 0.12^{*} \\
(4.92-7.15)\end{array}$ \\
\hline Patients without GOR & 4 & $14 \dagger$ & $12 \dagger$ \\
\hline
\end{tabular}

(Mean \pm SEM, range in parentheses ${ }^{*} P<0.05$ vs placebo. $\dagger P<0.01$ vs placebo).

TABLE IV Incidence of very acid GOR $(\mathrm{pH}<2.5)$

\begin{tabular}{lclcl}
\hline & PLAC & RANIM & RANIV & $P$ \\
\hline Before anaesthesia & 9 & 3 & 2 & $<0.01$ \\
& $(1-4)$ & $(1-3)$ & $(1)$ & \\
During anaesthesia & 10 & 1 & 4 & $<0.01$ \\
& $(1-3)$ & $(1)$ & $(1-3)$ & \\
After anaesthesia & 4 & 0 & 4 & NS \\
Total incidence of very acid & $(4-7)$ & $(0)$ & $(1-2)$ & \\
GOR $(n)$ & 44 & 9 & 14 & $<0.05$ \\
\hline
\end{tabular}

(Data represent the number of patients with their range of episodes in parenthesis, $P$ indicates probability of differences vs placebo)

both ranitidine groups, but the number of acid reflux events after $90 \mathrm{~min}$ was reduced by half in the im group. Similarly the mean $\mathrm{pH}$ values during these episodes remained somewhat higher than in the $i v$ group. The sum of refluxes was the lowest in the im group. Oesophageal acid clearing was more efficient in this group as the duration of the reflux episodes decreased while the total number of long lasting reflux events $(>$ five minutes) was similar to the $i v$ group.

Some GOR is physiological in normal healthy persons. These episodes are asymptomatic and characterized by their short duration with rapid elimination of refluxed gastric acid fluid from the oesophagus. ${ }^{22}$ It is also commonly agreed that the barrier pressure (difference between gastric and lower oesophageal sphincter pressures) is the main determinant for creating gastric reflux. ${ }^{23}$ Although the gastroesophageal junction is more competent in the supine than in upright position and sleep does not affect this competence, many anaesthetic agents may influence its barrier function. The incidence of GOR in nonemergency asymptomatic surgical patients is usually overlooked and largely unknown. Pharyngeal regurgitation of acidic contents was not evaluated in this study, but our data indicate that a substantial number of healthy surgical patients may present a considerable oesophageal acid exposure during anaesthesia requiring prolonged periods to clear the oesophagus of gastric fluid. "Silent" regurgitation of gastric contents has been shown to occur in 5 to $20 \%$ of patients with incidences up to $30 \%$ during upper abdominal procedures. ${ }^{7,24,25}$ Factors which may elicit GOR included the type of surgery and hormonal concentrations of progesterone and oestrogens. ${ }^{23}$ But no relationships existed between GOR and age, sex, alcohol use, ${ }^{6}$ nor type of inhalation anaesthetic agent ${ }^{25}$ or muscle relaxant, ${ }^{7}$ nor position with the exception of the prone position. There is no evidence that GOR occurs during laparoscopy. ${ }^{25}$ Hardy et al. ${ }^{6}$ suggested recently that the risk of GOR on induction of anaesthesia was negligible despite gastric fluid volumes of $30 \mathrm{ml}$. However, Martin et al. ${ }^{27}$ found a five percent incidence of acid reflux into the oesophagus during anaesthesia in patients without clinical history of GOR. The discrepancy between these studies is probably related to differences in methodology, but they cast some doubt on the validity of using a gastric 
fluid volume of $25 \mathrm{ml}$ as a critical factor for the development of regurgitation pneumonia.

Many clinical studies have demonstrated the beneficial effect of $\mathrm{H}_{2}$-receptor antagonists on gastric $\mathrm{pH}$ and fluid volume. ${ }^{13-21}$ The results of this investigation confirm previous findings of reduced gastric acidity following ranitidine at times of tracheal intubation and extubation ${ }^{18-20}$ but, as Durrant et al. ${ }^{17}$ reported, there remain an important number of very acid GOR episodes $(\mathrm{pH}<2.5)$ despite ranitidine pretreatment. Based on the known pharmacokinetic behaviour of the drug, ${ }^{28,29}$ it was estimated that a single dose of ranitidine $50 \mathrm{mg}$ would be sufficient to reach and maintain the plasma concentration near the inhibitory concentration $\left(\mathrm{IC}_{50}\right.$ ) for acid secretion of $200 \mathrm{ng} \cdot \mathrm{ml}^{-1}$ for several hours. ${ }^{30}$ The differences observed in pharmacodynamic effect of ranitidine following $i v$ and im administration could possibly be explained by a longer maintenance of ranitidine plasma concentration within a therapeutic window following the im route.

Does ranitidine influence the mechanical aspects of GOR or is the observed reduction of GOR the consequence of its neutralizing effect on gastric secretion only? Gastroesophageal $\mathrm{pH}$ monitoring alone does not allow this question to be answered. However, Kravitz et al. showed that, in humans, histamine exerts a biphasic effect on the lower oesophageal sphincter mediated only by the $\mathrm{H}_{2}$-receptor with weak excitation at low doses and reversal of this effect at moderate doses. ${ }^{31}$ Despite being a specific $\mathrm{H}_{2}$-receptor antagonist, ranitidine does not affect oesophageal motility. ${ }^{32}$ When given before atropine, ranitidine was reported to produce a. net increase in lower oesophageal sphincter pressure ${ }^{33}$ although this has been disclaimed by others. ${ }^{32}$ Therefore, we do not know at present whether ranitidine influences the real incidence of reflux itself. Possibly a reduction of the gastric residual fluid volume may also influence the incidence of GOR. ${ }^{17-21}$

In conclusion, fewer episodes of acid gastroesophageal reflux were observed following a single parenteral administration of ranitidine. The $\mathrm{pH}$ of such episodes was less acid than in placebo treated patients. Both factors reduced the total time of oesophageal exposure to gastric acid. However, protection against GOR was not complete; a considerable number of very acid refluxes occurred in patients in both ranitidine groups.

\section{References}

1 Mendelson $C L$. Aspiration of stomach contents into the lungs during obstetric anesthesia. Am J Obstet Gynecol 1946; 53: 191-205.

2 Kaunitz AM, Hughes JM, Grimes DA, Smith JC, Rochat $R W$, Kafrissen $M E$. Causes of maternal mortality in the United States. Obstet Gynecol 1985; 65: 605-12.
3 Olsson GL, Hallen B, Hambraeus-Jonzon K. Aspiration during anaesthesia: a computer-aided study of 185,358 anaesthetics. Acta Anaesthesiol Scand 1986; 30: 84-92.

4 James CF, Modell JH, Gibbs CP, Kuck EJ, Ruiz BC. Pulmonary aspiration-effects of volume and $\mathrm{pH}$ in the rat. Anesth Analg 1984; 63: 665-8.

5 Hardy JF. Large volume gastroesophageal reflux: a rationale for risk reduction in the perioperative period. Can J Anaesth 1988; 35: 162-73.

6 Hardy JF, Lepage Y, Bonneville-Chouinard N. Occurrence of gastroesophageal reflux on induction of anaesthesia does not correlate with the volume of gastric contents. Can J Anaesth 1990; 37: 502-8.

7 Carlsson $C$, Islander $G$. Silent gastropharyngeal regurgitation during anesthesia. Anesth Analg 1981; 60: 665-7.

$8 O^{\prime} M u l l a n e ~ E J$. Vomiting and regurgitation during anaesthesia. Lancet 1954; 1: 1209-12.

9 Heading $R C$. Epidemiology of oesophageal reflux disease. Scand J Gastroenterol 1989; 24: 33-7 (suppl. 168).

10 Wienbeck $M$, Barnert J. Epidemiology of reflux disease and reflux esophagitis. Scand J Gastroenterol 1989; 24: 7-13 (suppl. 156).

11 Nebel OT, Fornes MF, Castell DO. Symptomatic gastroesophageal reflux: incidence and precipitating factors. Dig Dis 1976; 21: 953-6.

12 Daly MJ, Humphray JM, Stables $R$. Inhibition of gastric acid secretion in the dog by the $\mathrm{H}_{2}$-receptor antagonists, ranitidine, cimetidine, and metiamide. Gut 1980;21: 408-12.

13 Desechalliers JP, Galmiche JP, Touchais JY, Denis $P$, Colin $R$. Ranitidine, cimetidine, antacids and gastro-esophageal reflux: results of a 20-hour oesophageal $\mathrm{pH}$ study. Int $\mathrm{J}$ Clin Pharmacol Res 1984; 4: 217-22.

14 Domschke W, Lux G, Domschke S. Furan $\mathrm{H}_{2}$-antagonist ranitidine inhibits pentagastrin-stimulated gastric secretion stronger than cimetidine. Gastroenterology 1980; 79: 1267-71.

15 Dammann HG, Muller $P$, Simon $R$. Parenteral ranitidine: onset and duration of action. Br J Anaesth 1982; 54 : $1235-6$.

16 Williams $J G . \mathrm{H}_{2}$-receptor antagonists and anaesthesia. Can Anaesth Soc J 1983; 30: 264-9.

17 Durrant $J M$, Strunin $L$. Comparative trial of the effect of ranitidine and cimetidine on gastric secretion in fasting patients at induction of anesthesia. Can Anaesth Soc J 1982; 29: 446-51.

18 Morison DH, Dunn GL, Fargas-Babjak AM, Moudgil $G C$, Smedstad K, Woo J. A double-blind comparison of cimetidine and ranitidine as prophylaxis against gastric aspiration syndrome. Anesth Anal 1982; 61: 988-92.

19 Maile CJD, Francis RN. Preoperative ranitidine. Effect of a single intravenous dose on $\mathrm{pH}$ and volume of gastric aspirate. Anaesthesia 1983; 38: 324-6. 
20 Manchikanti $L$, Colliver $J A$, Grow $J B$, Demeyer $R G$, Hadley $C H$, Roush JR. Dose-response effects of intravenous ranitidine on gastric $\mathrm{pH}$ and volume in outpatients. Anesthesiology 1986; 65: 180-5.

21 Williams JG, Strunin $L$. Preoperative intramuscular ranitidine and cimetidine. Double-blind comparative trial, effect on gastric $\mathrm{pH}$ and volume. Anaesthestia 1985; 40: 242-5.

22 Demeester TR, Johnson LF, Joseph GJ, Toscano MS, Hall $A W$, Skinner $D B$. Patterns of gastroesophageal reflux in health and disease. Ann Surg 1976; 184: 459-70.

23 Cotton BR, Smith $G$. The lower oesophageal sphincter and anaesthesia. Br J Anaesth 1984; 56: 37-46.

24 Turndorf H. Rodis ID, Clark TS. "Silent" regurgitation during general anesthesia. Anesth Analg 1974; 53: 700-3

25 Blitt CD, Gutman HL, Cohen DD, Weisman H. Dillon $J B$. "Silent" regurgitation and aspiration during general anesthesia. Anesth Analg 1970; 49: 707-13.

26 Roberts CJ, Goodman NW. Gastroesophageal reflux during elective laparoscopy. Anaesthesia 1990; 45: 1009-11.

27 Martin C. Auffray J, Ragni J, Guillen J, Auge A, Lambert $D$, Gouin $F$. Measurement of lower oesophageal $\mathrm{pH}$ during induction of anaesthesia: use of oesophageal probe. Acta Anaesthesiol Scand 1992; 36: 226-9.

28 McNeil JJ, Mihaly GW, Anderson A, Marshall AN, Smallwood RA, Louis WJ. Pharmacokinetics of the $\mathrm{H}_{2}$-receptor antagonist ranitidine in man. $\mathrm{Br} \mathrm{J}$ Clin Pharmacol 1981; 12: 411-5.

29 Chau NP, Zech PY, Pozet N, Hadj-Aissa A. Ranitidine kinetics in normal subjects. Clin Pharmcol Ther 1982; 31: 97-101.

30 Brogden RN, Carmine AA, Heel RC, Speight TM, Avery $G S$. Ranitidine: a review of its pharmacology and therapeutic use in peptic ulcer disease and other allied diseases. Drugs 1982; 24: 267-303.

31 Kravitz JJ, Snape WJ, Cohen $S$. Effect of histamine and histamine antagonists on human lower esophageal sphincter function. Gastroenterology 1978; 74: 435-40.

32 Denis P, Galmiche JP, Ducrotte P, Colin R, Pasquis $P$, Lefrancois $R$. Effect of ranitidine on resting pressure and pentagastrin response of human lower esophageal sphincter. Dig Dis 1981; 26: 999-1002.

33 Brock-Utne JG, Downing JW, Humphrey D. Effect of ranitidine given before atropine sulphate on lower oesophageal sphincter tone. Anaesth Intensive Care 1984; 12: 140-2. 